\title{
GOVERNMENT INDEMNITY RIGHTS UNDER THE SOLDIERS' AND SAILORS' RELIEF ACT OF 1940
}

'The Soldiers' and Sailors' Civil Relief Act of $1940^{1}$ was intended to mitigate the economic burdens of military service primarily by suspending the enforcement of certain civil liabilities against service personnel. ${ }^{2}$ To this end, one article of the act guaranteed payment by the Government of the serviceman's life insurance premiums in order to prevent a lapse during his term of service. ${ }^{3}$. But if, within one year after termination of his military service, an insured failed to pay all past due premiums, the policy was to lapse, and the insurer was to credit the United States with the cash surrender value to the extent necessary to indemnify the United States for the obligation incurred under its statutory guarantee. ${ }^{4}$

\footnotetext{
${ }_{54}^{2}$ STAT. II78 (1940), as amended, 50 U.S.C. $\$ 501$ (1952).

'The 1940 Act is a virtual re-enactment of the Soldiers' and Sailors' Civil Relief Act of I9I8, 40 STAT. 440, and offers protection in four major areas: general relief; rent, installment contracts, and mortgages; insurance; and administrative remedies. It does not attempt to suspend all civil liability of the serviceman during his term of duty, but provides that relief will be granted only in the event that a serviceman is unable to "pay or perform" by reason of his military service. The law review treatment of the act has been extensive. Among the more comprehensive articles are: Bendetson, $A$ Discussion of the Soldiers and Sailors Civil Relief Act of 1940, 2 WASH. \& LEE L. REv. I (1940); Jensen, Civil Relief for Soldiers and Sailors: A Critical Analysis, 36 ILL. L. REv. 325 (194I); Landis, Soldiers' and Sailors' Civil Relief Act, 47 Drck. L. REV. I29 (I943). For a good bibliography of books, cases and articles, see Schmehl, Soldiers' and Sailors' Civil Relief Act of 1940, 35 L. LIB. J. I87 (1942), 37 L. Lib. J. 4 (1944).

${ }^{3}$ Art. IV-Insurance. 54 STAT. I I83-86 (1940), 50 App. U.S.C. $\$ \S 540-54$ (1952).

"The pertinent provisions of the act, as originally enacted, were: $\S 405$ : "No policy which has not lapsed for the nonpayment of premium before the commencement of the period of military service of the insured, and which has been brought within the benefits of this article, shall lapse or be forfeited for the nonpayment of premium during the period of such service or during one year after the expiration of such period. . .." 54 STAT. 1184 (1940). This section of the 1940 Act was deleted by the 1942 amendments, 56 STAT. 775 (1942); but its protection was continued in force by 56 STAT. 776 (1942), 50 App. U.S.C. $\$ 548$ (1952). See 50 App. U.S.C. $\$ 545$ (1952).

\$ 410: "If the insured does not within one year after the termination of his period of military service pay to the insurer all past due premiums with interest thereon from their several due dates at the rate provided in the policy for policy loans, the policy shall at the end of such year immediately lapse and become void, and the insurer shall thereupon become liable to pay the cash surrender value thereof, if
} 
Curiously, the act gave no definite indication as to whether the cash surrender value was to be the Government's sole source of indemnification, or whether the Government could proceed against the serviceman personally to recover any deficiency. ${ }^{5}$ The significance of this statutory omission, which was remedied by amendment in $1942,{ }^{\circ}$ is accentuated by the fact that the cash surrender value has quite frequently been inadequate to compensate the Government for its expense. ${ }^{7}$ Also, there remain, even now, many thousands of persons whose policies were supported under the 1940 Act and against whom the indemnity rights of the United States are uncertain. ${ }^{8}$ The difficulty is further compounded by the fact that the courts that have considered the problem are hopelessly divided; and, even among those cases in which results have been consonant, there is considerable variation as to the asserted underlying rationale.

For example, a New York district court, in Hormel v. United States, held that the Government has no right of action against the insured personally because of the complicated ssytem provided by the act for

any. ..." 54 STAT. II85 (1940), 50 App. U.S.C. \$ 550 (1952) [omitted from the act by the 1942 amendments, 56 STAT. 773 (1942)].

$\S_{4} \mathrm{II}$ : "At the expiration of one year after the date when this Act ceases to be in force there shall be an account stated between each insurer and the United States, in which there shall be credited to the insurer the total amount of the certificates held as security under this article, together with accrued interest to the date of the account, and in which there shall be credited to the United States the amount of the cash surrender value of each policy lapsed or forfeited as provided in Section 410, but not in any case a greater amount on any policy than the total of the unpaid premiums with interest thereon at the rate provided for in the policy for policy loans." 54 STAT, 1185 (1940), 50 App. U.S.C. $§ 551$ (1952) [omitted by the 1942 amendinents, 56 STAT. $773(1942)]$.

${ }^{2}$ The omission occurs in $\S 4 \mathrm{II}$. See note 4 , supra.

${ }^{6} 56$ STAT. 775 (1942), 50 App. U.S.C. $\$ 546$ (1952). As amended, the statute now provides: "The amount paid by the United States to an insurer on account of applications approved under the provisions of this article, as amended, shall become a debt due to the United States by the insured on whose account payment was made and, notwithstanding any other Act, such amount may be collected either by deduction from any amount due said insured by the United States or as otherwise authorized by law."

${ }^{7}$ Letter from Guy H. Birdsall, Acting General Counsel for the Veterans' Administration, to the Duke Bar Journal, March $16,1956$.

${ }^{8}$ Ibid. The correspondence points out that a number of suits have been referred to the Justice Department for litigation, and that others are imminent, since some of the servicemen who received protection under the 1940 Act are still in the service. The correspondence also remarks that the cash surrender value of the policies is often inadequate to cover the amount paid by the Government, for the cost of the risk is less than the premium paid. 
settling accounts between the United States and an insurer. ${ }^{9}$ To avoid individual settlement of policies, the act provided for a lump-sum settlement with each insurer, the balance owing to be the difference between the total of the unpaid premiums with interest at three per cent and the cash surrender value of all the lapsed policies with interest at the policy loan rate. The court reasoned that any difference in the rates of interest accruing to the Goverment and to the insurer made it impossible to determine how much of the Government's lump-sum payment was made for any one policy; therefore, the amount that the Government should recover from any one serviceman could not be computed. ${ }^{10}$ Thus, the court concluded that Congress could not have intended to impose such liability.

By way of contrast, the Court of Appeals for the Ninth Circuit, in United States $v$. Plesha, ${ }^{11}$ also concluded that the Government's right to indemnity was restricted to the policy's cash surrender value, but emphasized entirely different factors. In particular, the court here was impressed by the fact that the application form for insurance coverage under the act made reference only to the policy's cash surrender value in defining the applicant's obligation. ${ }^{12}$. The court also considered significant both the 1942 amendment, which clearly imposes on servicemen a personal liability for the premiums paid by the Government, and a prior decision indicating that the act should be liberally interpreted in the servicemen's favor. ${ }^{13}$

\footnotetext{
${ }^{\circ}$ 123 F. Supp. So6 (S.D.N.Y. 1954).

${ }^{10}$ The court illustrates the problem by the following example. Both $A$ and $B$ have past due premiums; $A$ 's amount to $\$ 100$ with policy loan interest at $5 \%$ (the average rate on these policies) for one year, and his policy has a surrender value of $\$ 200$. $B$ has past due premiums of $\$ 200$, with interest at $5 \%$ for two years and his policy has a surrender value of $\$ 175$. Credited to the insurer are the past due premiums plus interest at $3 \%$ (the current rate paid by the government), so that the amount payable by the Government totals $\$ 315$. Credited to the Government is the cash surrender value of $B$ 's policy, $\$ 175$, and the premiums and interest of $A$ 's policy, $\$ 105$. This leaves an excess credit due the insurer of $\$ 35$, for which the Government may charge $B \$ 45$, the amount by which the debt on his policy exceeds the surrender value, if the debt were actually due the Government. If $A$ and $B$ were the sole veterans protected, who should pay the debt? $I d$. at $8 \mathrm{I} 4-\mathrm{r} 6$.

${ }^{11} 227$ F.2d 624 (9th Cir. 1955).

${ }^{12}$ Each applicant signed the following application: ". . I hereby consent and agree that the United States shall be protected in the amount of any premiums and interest .... in the event of its maturity as a claim, or out of the cash surrender value of the policy, at the expiration of the period of protection. ..." The court points out that from reading the statute, the appropriate regulations and the above form, an applicant could not infer any personal obligation to reimburse the Government. Id. at 626 .

${ }^{13}$ In Boone ซ. Lightner, 319 U.S. $56 \mathrm{r}$ (1943), Justice Jackson stated that, "The
} 
On the other hand, in Morton $v$. United States, ${ }^{14}$ another New York district court simply refused to impute to Congress an intention "to make a gift" to the holders of private insurance and, accordingly, concluded that the act must be taken to impose a personal liability on servicemen for any deficiency. ${ }^{15}$ An Iowa district court arrived at the same result, but was influenced by a variety of other factors. ${ }^{16}$ Thus, the latter court observed that the 1942 amendment, which was explicit in its imposition of personal liability on servicemen, was thought to be no more than a clarification of existing law. ${ }^{17}$ This court also relied on an obviously inconclusive exchange of remarks on the house floor, ${ }^{18}$ considered the relevance of certain contemporaneous legislation, ${ }^{10}$ and finally concluded that Congress did not intend to abrogate the Government's common-law right of reimbursement as a guarantor. And in United States v. Hendler, ${ }^{20}$ the Court of Appeals for the Tenth Circuit, persuaded both by the 1942 amendment and by the act's over-all purpose, held that the usual rules of guarantyship were intended to apply.

It is apparent that an objective evaluation of the various indicia relied on by the courts would not lead inevitably to one conclusion or the other; for, it seems obvious that Congress never considered the problem at all. Fortunately, however, resolution of the matter has been prom-

Soldiers' and Sailors' Civil Relief Act is always to be liberally construed to protect those who have been obliged to drop their own affairs to take up the burdens of the nation." Id. at 575 . See 42 Mich. L. REv. 183 (1943).

${ }_{14}{ }_{11}$ F. Supp. 496 (E.D.N.Y. 1953).

${ }^{15}$ The court felt that to make such a "gift" to servicemen protected by private insurance would discriminate against those who were without such insurance. $I d$, at 500.

${ }^{10}$ United States ข. Nichols, 105 F. Supp. 543 (N.D. Iowa 1952).

${ }^{17}$ The problem faced, of course, was whether the 1942 amendinent merely codified the existing law, or whether it created new law, not in effect under the original act. Cf. I SUtherLand, Statutory Construction $\$ \S$ 1929-39 (Horack ed. 1943).

${ }_{10}^{18}$ F. Supp. 543, 553-54 (N.D. Iowa 1952). This exchange emphasizes the fact that the statute demands of each applicant that he reimburse the Government for back premiums paid if he wishes to prevent the lapse of his policy. Unfortunately it sheds little light on the problem of whether the serviceman shall be personally liable for a deficit after a lapse.

${ }^{10} I d$. at $55^{8}$. The contemporaneous legislation referred to was the National Service Life Insurance Act, 54 STAT. 1008 (1940), as amended, 38 U.S.C. \$ 801 (1952). This act offered each serviceman the opportunity to protect himself with low cost life insurance, the premiums of which were to be paid from his salary. Virtually all servicemen took advantage of the program since the policies covered battle deaths, a risk generally excluded from private insurance contracts.

2022 F.2d 106 (roth Cir. 1955). 
ised by a grant of certiorari to the Court of Appeals for the Ninth Circuit for review of the decision in United States v. Plesha. ${ }^{21}$

But the variance in the approaches to the problem among the several courts has a significance that perhaps transcends the narrow problem itself. There has long been recognized a distinction between "genuine" and "spurious" statutory interpretation, which is fundamental to the judicial process. ${ }^{22}$ It is quite appropriate for a court, by interpretation, to attempt to discern the best meaning attributable to an imperfect expression of a legislative intent. It is not thought proper, however, for courts, by interpretation, to supplement the plain expression of an imperfect legislative intention. The courts that decided the above cases, however, seem to have done just that. Preferably they should have candidly recognized that Congress omitted to consider the matter in issue, and, adhering to the only expressed meaning of the imperfect statute, should have limited the Government's indemnity rights to the policy cash surrender value. This more ingenuous approach would not have led to such incongruous discoveries of a nonexistent legislative intent.

\footnotetext{
${ }_{24} 24$ U.S.L. WeEk 3265 (U.S. April 10, 1956) (No. 718.).

22 "Genuine" statutory interpretation may involve the application of a rule of construction, a search for the intent of the legislature, or a determination of the evil which a particular statute is designed to remedy. The problems of interpretation presented in the majority of cases can be resolved by resorting to one or all of these devices. Not infrequently, however, the legislaturc, through oversight or a failure to comprehend the problem, may enact a law which later is shown to be denciont when applied to a particular fact situation. Some courts in these instances will read into the statute a nonexistent legislative intent by means of "spurious" interpretation. This practice has been condemned as a judicial usurpation of the legislative function. See Pound, Spurious Interpretation, 7 CoLUM. L. Rev. 379 (1907); Landis, A Note on "Statutory Interpretation," 43 HARV. L. REV. 886 (1930).
} 